\title{
Evaluation of Key Determinants of Fraud Free Financial Report: a Focus on Nigeria
}

\author{
Nenyiaba Ile Charles ${ }^{1}$, Okoye Emma I. ${ }^{1}$ \\ ${ }^{1}$ Department of Accountancy, Nnamdi Azikiwe University, Awka, Anambra State, Nigeria \\ Correspondence: Nenyiaba Ile Charles, Department of Accountancy, Nnamdi Azikiwe University, Awka, Anambra State, \\ Nigeria
}

Received: March 17, 2015 Accepted: April 30, 2015 Online Published: May 13, 2015

doi:10.11114/bms.v1i2.819 URL: http://dx.doi.org/10.11114/bms.v1i2.819

\begin{abstract}
The study evaluated the key determinants of fraud free financial reports. Descriptive research design was used. Two null hypotheses were tested using Z-test for proportion, F statistics and Microsoft excel 2010 toolpak. The study revealed that there is significant relationship amongst the following variables; Accounting Standards, Corporate Governance and Internal Controls in determining Fraud Free Financial Report. Furthermore, that in Nigeria to obtain Fraud Free Financial Report emphasis was on Accounting Standards, Internal Controls and Corporate Governance in this order and, Auditor's Independence, Whistle Blowing and Accountants' Education received little or no attention. It also revealed that from extant literature Accounting Standards are tools for combating $25 \%$ of the eight elements in fraud management cycle while $75 \%$ of them are within the purview of Forensic accounting. Hence it recommended that forensic accounting courses should be incorporated into the curriculum of professional accounting institutes in order to equip their members with sufficient skills that would enable them effectively perform their duties as public accountants.
\end{abstract}

Keywords: fraud free financial reports, corporate governance, internal controls, whistle blowing, accountant education and independent of auditors

\section{Introduction}

The incidences of fraud ridden financial reports are rampant globally and there are no obvious signs that the incidences would abate. In Nigeria context Osisioma (2012) succinctly put the matter thus:

Fraud is systemic in Nigeria ... Fraud has stultified growth and national development and subverted the national values and norms ... Any remedial measure that does not address core and ingrained character defects in leaders and followers will not attract great success .... What is needed is a strong accountability framework an integrity system ... and a new generation of leaders.

Ayittey (2006) stated the shocking effect of such frauds in Africa by asserting that it is common knowledge that heads of state, ministers, and highly placed African government officials raid the African treasury, misuse their positions in government and deposit the loots from such fraudulent acts in overseas banks.

Brett (2006) on his part drew the world's attention to "Crazy Eddie" scandal especially the confession of Sam Antar the Chief Financial Officer of the company. He asserted that internal controls, auditor independence, accountant education, and sound corporate governance are the four pillars that ensure the soundness of financial report. He argued that the four must all work together for accounting standards to be properly implemented. However, the major kernel of his postulate is that the accounting profession training is deficient in tackling fraud because courses such as Criminal Psychology, Interview Skills are not covered in their syllabi. That a minority of universities and colleges offer a specific fraud class and that most of the schools offer it as an elective course at best. Furthermore, that students are not even taught how to ask proper questions or conduct field interviews that are necessary to carry out an audit of financial statement.

Although there are plethora of studies on fraud, implementation and compliance with accounting standards in Nigeria (Oghuma and Iyoha, 2005) to the best of our knowledge no study has established the extent to which we can rely on accounting standards or other accounting measure to discern or unravel fraud in financial reports. This study intends to fill the knowledge gap. 


\subsection{Statement of Problem}

Arising from the foregoing, it has become imperative to ascertain the extent to which we can rely on Accounting Standards and other accounting measures such as Sound Corporate Governance, Internal Control, Auditors' Independence, Enhance Accounting Education and Whistle Blowing to combat fraud and hence ensure Fraud Free Financial reports.

\subsection{Research Objective}

The overall purpose of this study is to evaluate the extent to which Accounting Standards and other Accounting measures can ensure production of Fraud Free Financial Reports. The specific purposes of the study are as follows:

i. Investigate the extent to which each of the following can ensure production of Fraud Free Financial Report; Accounting Standards (International Financial Reporting Standards inclusive), Sound Corporate Governance, Internal Controls, Auditors Independence, Accountants Education and Whistle Blowing.

ii. Ascertain whether or not accounting courses in Nigerian Professional Accounting Institutes' syllabi can sufficiently equip Accountants with relevant skills required to detect/curb fraud.

\subsection{Research Questions}

i. To what extent does each of the following; Accounting Standards, Sound Corporate Governance, Internal Control, Auditors Independence, Accountants Education and Whistle Blowing ensures fraud free financial reports?

ii. How are courses in Nigerian Professional Accounting Institutes' syllabi relevant in ensuring that Accountants have correct skill to detect and/or prevent fraud?

\subsection{Hypotheses}

i. There is no significant relationship amongst the following variables; Compliance with Accounting Standards, Sound Corporate Governance, Internal Controls, Auditors Independence, Accountants Education, Whistle Blowing and Fraud Free Financial Report.

ii. Near absence of forensic accounting courses in the training programme of practicing accountants is not responsible for inability of auditors to detect fraud.

\subsection{Scope of the Study}

This study dealt with frauds in financial reports. The empirical analysis was carried out using data from existing twenty four commercial banks and Governments of Nigeria (Federal, State and Local).

\subsection{Significance of the Study}

This study evaluates key determinants of Fraud Free Financial Report. Frauds and similar irregularities occurrence are as old as man (Financial Institution Training Centre (FITC), 2013) and it is self-evident that the level of their sophistication is the same as that of the human society at any point in time in which they occurred. Therefore, at each point in time the challenges of fraud will vary globally. Consequently, it behooves human society to continually assess the means by which they are combating the menace and accountancy is not an exception.

\section{Conceptual Framework}

Fraud has received considerable attention in literature. This study however pertains to the application of Accounting Standards, Corporate Governance, Internal Controls, Auditors Independence, Accountants Education and Whistle Blowing to combat fraud. We are to evaluate the presumed relationship amongst them. The relationship can be conceptualized at a fairly general level as shown below. 


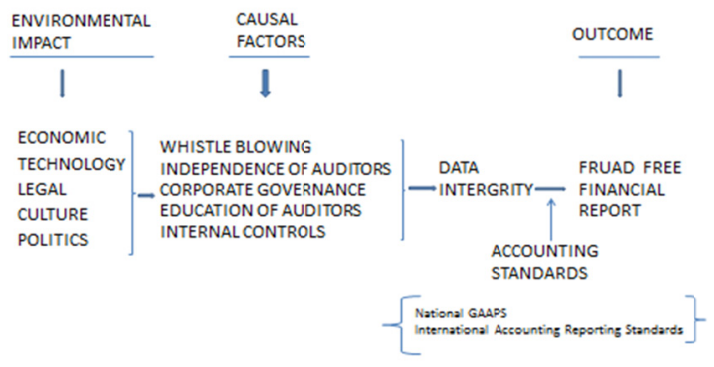

Source: Researcher's design, 2014

Figure 1. Schematic Diagram of the Constructs

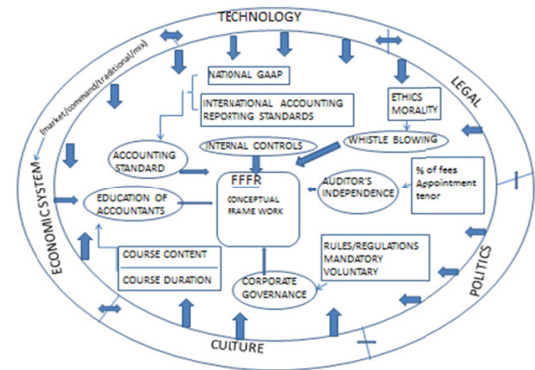

Figure 2. Process Flow of the Constructs

Source: Researcher's design, 2014.

The outer layer of figure 2 contains environmental factors namely; economy, technology, legal, politics and culture that impinges on each other and also impinges on the variables in the inner cycle. The main variables (in the inner cycle) are Accounting Standards, Education of Accountants, Corporate Governance, Auditors Independence, Internal Controls and Whistle Blowing while the subordinated variables to each of them are in rectangular boxes. Notice that all of the variables impact on FFFR (core of the inner cycle).

Indeed, the type of economy a country is operating impacts the rate of fraud in the country. For instance, in our view, in a market economy the severity of competition therein influences the level of corruption in the economy - the macro effects.

In the milieu of the above scheme, we abstracted the main variables (Accounting Standards, Internal Controls, Education of Accountants, Corporate Governance, Auditors Independence, and Whistle Blowing) for close examination with a view to ascertaining the key determinants of FFFR and the extent to which each of them can unravel fraud both at country and firm levels.

\section{Theoretical Framework}

As part of our evaluation of determinants of fraud free financial report we examined Wesley and Wilhelm (2004) Fraud Management Lifecycle which according to them comprises eight stages. The theory dealt with the actions, activities, processes, procedures, organizational designs, economic analysis, and intra-entity exchanges necessary to manage and reduce the impact of fraudulent activity. However, we do not agree with the use of the words "life cycle" in the caption of their theory because, in our opinion, life cycle implies a continuum of birth, maturity and death which is not the case in their theory under discussion. A better title, in our view, should be "Steps in Fraud Management".

The first step is deterrence which is characterized by actions and activities intended to stop or prevent fraud before it is attempted. The second step is prevention which entails actions and activities to prevent fraud from occurring. The third step is detection which includes actions and activities, such as statistical monitoring programs used to identify and locate fraud prior to, during, and subsequent to the completion of the fraudulent activity. The intent of detection is to uncover or reveal the presence of fraud or a fraud attempt.

Mitigation is the fourth step. It comprises measures aimed at stopping losses from occurring or continuing to occur and/or hinder a fraudster from continuing or completing the fraudulent activity. The fifth step is analysis (such as root cause analysis) which is identification and study to determine factors responsible for loss situation that occurred despite deterrence, detection, and prevention activities. The sixth step is policy which is characterized by activities to create, evaluate, communicate, and assist in the deployment of policies to reduce the incidence of fraud. Policy such as "any cash transaction over N100,000 must be reported to the Managing Director". 
Investigation which is the seventh step involves obtaining enough evidence and information to stop fraudulent activity, recover assets or obtain restitution, and provide evidence and support for the successful prosecution and conviction of the fraudster(s). According to them electronic surveillance is a method used in this stage. The final step is prosecution stage which is the culmination of all the successes and failures in steps in Fraud Management. This stage includes asset recovery, criminal restitution, and conviction.

Interestingly, in the steps, in our opinion International Accounting Reporting Standards appears to be means for ensuring deterrence and prevention of fraud only, about $25 \%$ of the steps. The rest of the steps $75 \%$ appear to be within the purview of forensic accounting. We note that extant theories did not establish the extent to which we can rely on each of the main constructs in our model in this study which are compliance with accounting standards, internal controls, accountants education, auditors independence and whistle blowing to discern or unravel fraud.

\subsection{Empirical Studies}

Many studies have been carried out on compliance with accounting standards amongst them are: Oghuma and Iyoha (2005) investigated the level of compliance of listed insurance companies to accounting standards, Izedomin (2001) investigated the level of compliance to accounting standards in the banking industry. Adeyemi (2005) on his part studied the impacts that compliance has on financial reporting. From a study of 96 companies, the study revealed that Nigerian companies comply with accounting standards but that the level of compliance is less than the international benchmark of $91 \%$, and there are variations in the depth of disclosure by the companies studied. On the impact compliance has on financial reporting, the study revealed that there is a significant positive impact and that there is no significant relationship between audit firms' size and compliance with accounting standards in Nigeria. The author work is similar to Wallace (1988) that also examined disclosure practice by Nigerian companies, in compliance with Nigerian accounting standards and the study revealed that company size, ownership structure, company age, multinational affiliation, auditors' size, number of employees, stock exchange listing and profitability are associated with disclosure level.

Despite the extensive local and international research on IARS implementation, no study has been conducted in Nigeria on the use of IARS as a WCC combating tool. Moreover, the extensive international findings on IARS implementation may not be applicable to Nigeria, in our opinion research methods and results are influenced by economic, social or legal realities in those countries in which the studies took place. As stated above this is the knowledge gap this study is addressing.

\section{Research Methodology}

\subsection{Research Design}

The study adopted the survey and documentary research techniques. The primary data used for the study were obtained through the administration of structured questionnaire to respondents. The questionnaire was adapted from Iyoha (2011). The respondents are accounting staff of Accountant General office, accounting staff of office of the Auditor General and bankers. The specialise nature of this study made it imperative to seek responses from such calibre of persons because their accounting qualifications and exposures are to add credibility to the findings of the study.

The study used descriptive statistics (averages, percentages etc) and inferential statistics (those obtained from the regression analysis). First, the responses to the questionnaire were analyzed by using descriptive statistics: frequencies, means and standard deviation. Thereafter Z-test for proportion, t-test, F statistics and Microsoft excel 2010 toolpak for OLS regression were deployed for the inferential statistics.

\subsection{Study Population}

The bank subsector and the public sector are targeted in the study. Nigeria has twenty four banks out of which sixteen of them are listed (Fact book 2011/12). The public sector comprised a Federal Government, thirty six State Governments and a Federal Capital Territory. The targeted professionals (Accounting and Banking) in this study are members of Institute of Chartered Accountants of Nigeria (ICAN), Association of National Accountants of Nigeria (ANAN) and Chartered Institute of Banker of Nigeria (CIBN). Their membership size as at $31^{\text {st }}$ December 2013 is as below.

Table 1.Professionals Targetted in the Study

\begin{tabular}{|c|c|c|}
\hline Institute & & Membership Size \\
\hline Anan & & 13,717 \\
\hline Ican & & 37,552 \\
\hline Cibn & & 72,731 \\
\hline & Total & 124,000 \\
\hline
\end{tabular}

Source: Compiled by the Researcher from the annual reports of the institutes and their membership register. 


\subsection{Sample Size}

We adopted Ezejelue, Ogwo and Nkamnebe (2008) sampling technique as shown below. According to the scholar;

There is often no satisfactory generalization on what the appropriate sample size should be... several rules of thumb however exist for estimating the size of a sample. The most common is the $1 / 10$ th rule, which states that the researcher should try to obtain $1 / 10$ th of the population he studies in his sample... some cases sample size ... less than $1 / 10$ th $\quad \ldots$ would satisfy the research requirement.

Of the total membership of 124,000 professionals as stated above, we made conservative estimates of their number in each of the sector and subsector from which we drew our sample size $(1,000$ members) for examination as shown below. 
Table 2. Targeted Professionals for the Survey

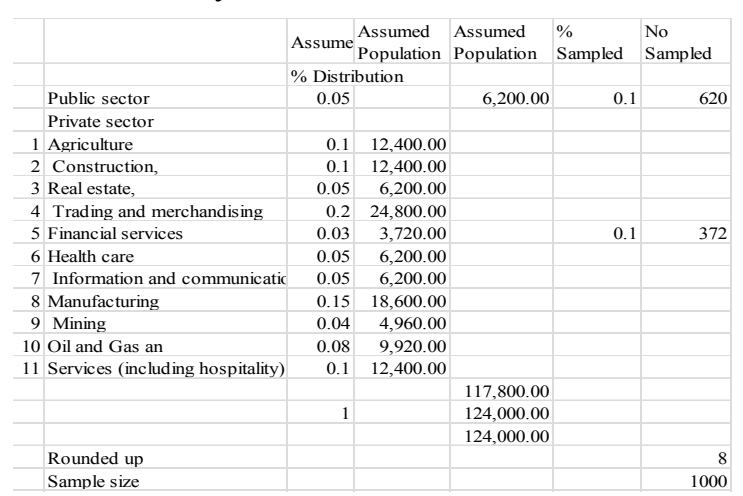

Source: Compiled by the Researcher (2014).

Using stratified sampling technique on the population, the 10 States we chose for distribution of the questionnaire was arrived at as shown below.

Table 3. Stratify Population Sampling

\begin{tabular}{|c|c|c|c|c|c|}
\hline & First Band & Second Band & Third Band & Fourth Band & \\
\hline & 4 Million and Above & 3 Million and Below $4 \mathrm{~m}$ & 2 Million and Below $3 \mathrm{~m}$ & Below 2 Million & Total \\
\hline No of States & 12 & 14 & 6 & 5 & 37 \\
\hline No of States Sampled & 3 & 4 & 2 & 1 & 10 \\
\hline$\%$ Sampled & 0.25 & 0.29 & 0.33 & 0.2 & 0.27 \\
\hline & \multicolumn{5}{|c|}{ Average: $27 \%$ of the population Were Sampled } \\
\hline & \multicolumn{5}{|c|}{ The Sampled States Are as Follows } \\
\hline & Delta & Edo & Cross River & \multirow{2}{*}{\multicolumn{2}{|c|}{ Bayesa }} \\
\hline & Lagos & Ondo & Ekiti & & \\
\hline & Kaduna & Ogun & Osun & & \\
\hline
\end{tabular}

Source: Compiled by the Researcher (2014)

A total number of 1,000 copies of the questionnaire as determined earlier were administered on the professionals in 10 States (as determine above) amounting to 100 copies to the banks and government institutions in each of the States. This outcome is adjudged acceptable (Ezejelue et al. (2008) as cited above).

\subsection{The Questionnaire}

Respondents were required to rank each of the parameters under examination. The rating scale was based on the level of importance that they attach to each of the items listed. A five-point Likert scale was used with a rating of (5) indicating very strong, (4) = strong, (3) = fairly strong, (2) = weak and (1) = very weak. This technique agrees significantly with that used by Iyoha (2011), Firer and Meth (1986) and Courtis (1992) and were adjudged very suitable. For sample of questionnaire see appendix.

\subsection{Model $A$ and B Formulation}

Model A was aimed at the impact of the following independent variables (predictors) on the dependent variable (response variable) Fraud Free Financial Report; Compliance with Accounting Standards, Internal Controls, Corporate Governance, Auditors Independence, Accountants Education and Whistle Blowing and the sub-model is based on the vector of Valuation Technique (VT), Application of Accounting Principles (AAP) and Disclosure (DIS) on the independent variable in model A. In other words we are also to test the dependence of these three variables on the independent variables (predictors) in model A.

Model A

The model which is investigating the impact of Accounting Standards, Internal Controls, Corporate Governance, Auditors Independence and Whistle Blowing on Fraud Free Financial Report is written in a functional form thus:

$$
\mathrm{FFFR}=\mathrm{f}(\mathrm{CS}, \mathrm{IC}, \mathrm{CG}, \mathrm{AI}, \mathrm{AE}, \mathrm{WB})
$$

Model B

The dependent variable FFFR is a vector of three components - VT, AAP and DIS such that the equations model B can be written as:

$$
\mathrm{VT}=\mathrm{f}(\mathrm{CS}, \mathrm{IC}, \mathrm{CG}, \mathrm{AI}, \mathrm{AE}, \mathrm{WB})
$$




$$
\begin{aligned}
& \mathrm{AAP}=\mathrm{f}(\mathrm{CS}, \mathrm{IC}, \mathrm{CG}, \mathrm{AI}, \mathrm{AE}, \mathrm{WB}) \\
& \mathrm{DIS}=\mathrm{f}(\mathrm{CS}, \mathrm{IC}, \mathrm{CG}, \mathrm{AI}, \mathrm{AE}, \mathrm{WB})
\end{aligned}
$$

Where:

VT: Valuation Technique

AAP: Application of Accounting Principles

DIS: Disclosure

The main and sub-models are specified into four multiple regression equations. The main model is model 1 and the sub-models are models 2 and 3. Model 1 utilized the composite pooled data while models 2 and 3 separately utilized composite data from responses by Public sector and Banking sub-sector respectively.

Assuming a linear relationship amongst the variables, the specification of the regression equations for the main model (1) and sub-models (2 and 3) above could be explicitly stated as:

Model 1

$$
\begin{gathered}
\mathrm{FFFR}=\alpha 0+\alpha 1 \mathrm{CS}+\alpha 2 \mathrm{IC},+\alpha 3 \mathrm{CG}+\alpha 4 \mathrm{AI}+\alpha 5 \mathrm{AE}+\alpha 6 \mathrm{WB}+\mathrm{u} 1 \\
\mathrm{VT}=\beta 0+\beta 1 \mathrm{CS}+\beta 2 \mathrm{IC}+\beta 3 \mathrm{CG}+\beta 4 \mathrm{AI}+\beta 5 \mathrm{AE}+\beta 6 \mathrm{WB}+\mathrm{u} 1 \\
\mathrm{AAP}=\varphi 0+\varphi 1 \mathrm{CS}+\varphi 2 \mathrm{IC}+\varphi 3 \mathrm{CG}+\varphi 4 \mathrm{AI}+\varphi 5 \mathrm{AE}+\varphi 6 \mathrm{WB}+\mathrm{u} 1 \\
\mathrm{DIS}=\psi 0+\psi 1 \mathrm{CS}+\psi 2 \mathrm{IC}+\psi 3 \mathrm{CG}+\psi 4 \mathrm{AI}+\psi 5 \mathrm{AE}+\psi 6 \mathrm{WB}+\mathrm{u} 1
\end{gathered}
$$

Model 2

The regression equations using the composite responses for Public Sector is as follows:

$$
\begin{aligned}
\text { PFFFR }=\alpha 0+\alpha 1 \mathrm{CS}+\alpha 2 \mathrm{IC}+\alpha 3 \mathrm{CG}+\alpha 4 \mathrm{AI}+\alpha 5 \mathrm{AE}+\alpha 6 \mathrm{WB}+\mathrm{u} 1 & \text { A5 } \\
\mathrm{PVT}=\beta 0+\beta 1 \mathrm{CS}+\beta 2 \mathrm{IC}+\beta 3 \mathrm{CG}+\beta 4 \mathrm{AI}+\beta 5 \mathrm{AE}+\beta 6 \mathrm{WB}+\mathrm{u} 1 & \text { A6 } \\
\mathrm{PAAP}=\varphi 0+\varphi 1 \mathrm{CS}+\varphi 2 \mathrm{IC}+\varphi 3 \mathrm{CG}+\varphi 4 \mathrm{AI}+\varphi 5 \mathrm{AE}+\varphi 6 \mathrm{WB}+\mathrm{u} 1 & \text { A7 } \\
\text { PDIS }=\psi 0+\psi 1 \mathrm{CS}+\psi 2 \mathrm{IC}+\psi 3 \mathrm{CG}+\psi 4 \mathrm{AI}+\psi 5 \mathrm{AE}+\psi 6 \mathrm{WB}+\mathrm{u} 1 & \text { A8 }
\end{aligned}
$$

Model 3

While the regression equation using the responses for the Banking Sector is as follows:

$$
\begin{array}{cc}
\mathrm{BFFFR}=\alpha 0+\alpha 1 \mathrm{CS}+\alpha 2 \mathrm{IC},+\alpha 3 \mathrm{CG}+\alpha 4 \mathrm{AI}+\alpha 5 \mathrm{AE}+\alpha 6 \mathrm{WB}+\mathrm{u} 1 & \mathrm{~A} 9 \\
\mathrm{BVT}=\beta 0+\beta 1 \mathrm{CS}+\beta 2 \mathrm{IC}+\beta 3 \mathrm{CG}+\beta 4 \mathrm{AI}+\beta 5 \mathrm{AE}+\beta 6 \mathrm{WB}+\mathrm{u} 1 & \mathrm{~A} 10 \\
\mathrm{BAAP}=\varphi 0+\varphi 1 \mathrm{CS}+\varphi 2 \mathrm{IC}+\varphi 3 \mathrm{CG}+\varphi 4 \mathrm{AI}+\varphi 5 \mathrm{AE}+\varphi 6 \mathrm{WB}+\mathrm{u} 1 & \mathrm{~A} 11 \\
\mathrm{BDIS}=\psi 0+\psi 1 \mathrm{CS}+\psi 2 \mathrm{IC}+\psi 3 \mathrm{CG}+\psi 4 \mathrm{AI}+\psi 5 \mathrm{AE}+\psi 6 \mathrm{WB}+\mathrm{u} 1 & \mathrm{~A} 12
\end{array}
$$

where:

FFFR: Fraud Free Financial Report: Is measured by averaging three items which represent different attributes of Fraud Free Financial Report-Valuation Technique, Application of Accounting Principles and Disclosures.

CS: Compliance with International Accounting Reporting Standard: This is measured by averaging nine items in the questionnaire and scores of the three attributes of FFFR viz Valuation Technique, Application of Accounting Principles and Disclosures.

IC: Internal Control: The impact is measured based on averaging six indicators in the questionnaire and the attributes of FFFR.

CG: Corporate Governance: The average of seven indicators in the questionnaire as well as the three attributes of FFFR.

AI: Auditors Independence: This is measured based on the average of five indicators in the questionnaire and three attributes of FFFR.

AE: Accountants Education: This is measured based on the average of five indicators in the questionnaire and the three attributes of FFFR. 
WB: Whistle Blowing: This is measured based on the average of five indicators in the questionnaire and the three attributes of FFFR.

U1: the error term capturing other explanatory variables not explicitly included

in the model. The parameters of the models are such that:

$$
\alpha 1, \alpha 2, \quad \ldots \ldots \ldots \ldots . \alpha 7>0
$$

Assumptions:

There is a linear relationship amongst the variables. The basis for the regression is that FFFR is anchored on three vectors namely; Valuation, Universality of principle and Vastness in disclosure. Moreover each of the major constructs under examination (CS, IC, SCG, AI, AE and WB) also depends on the vectors. To achieve FFFR the rating is from 1 to 5.

The above models are diagnostic and prognostic because their applications are at two levels; general and specific. The general level application establishes the relationship amongst the variables at country level using primary data from country-wide survey whose outcomes are reinforced by secondary data thereby establishing the grand norm, bench mark and paradigms for fraud free financial reports at the country level (diagnosis).

The specific level or firm level application on the other part, establishes the extent of deviation by the firm from the country level norms thereby revealing the firm's fraud risk (prognostic, redflag).

\section{Data presentation and Analyses}

Below are primary data collected during the study and outcomes of the tests we carried out on them. Interpretation and discussions of the results for each of the hypotheses tested followed immediately.

\subsection{Test on Hypothesis one}

We set out hereunder the outcomes of the tests we carried out on the models testing the extent to which each of the following; Accounting Standards, Sound Corporate Governance, Internal Control, Auditors Independence, Accountants Education and Whistle Blowing can ensure fraud free financial reports.

As stated earlier the basis for the regression is that FFFR is anchored on three vectors namely; Valuation, Universality of principle and Vastness in disclosure. Furthermore, each of the major constructs under examination (IARS, IC, SCG, AI, AE and WB) depends on the vectors as well. To achieve FFFR the rating is from 1 to 5 . Note also that the pivot of the model is the maximum score (5). That is the score in the intercept between the row and column of the FFR variable in the pool composite data table.

Ho: There is no significant relationship amongst the following variables; Compliance with Accounting Standards, Sound Corporate Governance, Internal Controls, Auditors Independence, Accountants Education, Whistle Blowing and Fraud Free Financial Report.

Table 4. Banks And Mdas Composite Data

\begin{tabular}{|c|c|c|c|c|c|c|c|}
\hline \multicolumn{8}{|c|}{ Composite Bank Data } \\
\hline & IARS & $\mathrm{CG}$ & IC & AI & $\mathrm{AE}$ & WB & \\
\hline AAP & 4.318471 & 4.180467 & 4.07431 & 4.212314225 & 4.14862 & 4.201699 & \\
\hline DIS & 4.242038 & 4.541401 & 3.987261 & 4.191082803 & 3.944798 & 4.04034 & \\
\hline VAL & 4.061571 & 4.031847 & 4.082803 & 4.029723992 & 3.997877 & 3.976645 & \\
\hline \multicolumn{8}{|c|}{ Composite Mda Data } \\
\hline & IARS & CG & IC & AI & $\mathrm{AE}$ & WB & \\
\hline AAP & 4.239651 & 3.856209 & 3.976035 & 3.860566449 & 3.912854 & 3.766885 & \\
\hline DIS & 4.04793 & 3.775599 & 3.943355 & 3.821350763 & 3.856209 & 3.633987 & \\
\hline VAL & 3.962963 & 3.718954 & 3.910675 & 3.840958606 & 3.712418 & 3.546841 & \\
\hline \multicolumn{8}{|c|}{ Composite Pool Data } \\
\hline & IARS & CG & IC & AI & $\mathrm{AE}$ & WB & FFFR \\
\hline FFFR & 4.145438 & 4.017413 & 3.99574 & 3.992666139 & 3.928796 & 3.861066 & 5 \\
\hline AAP & 4.279061 & 4.018338 & 4.025172 & 4.036440337 & 4.030737 & 3.984292 & 4.06234 \\
\hline DIS & 4.144984 & 4.1585 & 3.965308 & 4.006216783 & 3.900504 & 3.837163 & 4.002113 \\
\hline VAL & 4.012267 & 3.875401 & 3.996739 & 3.935341299 & 3.855148 & 3.761743 & 3.906106 \\
\hline
\end{tabular}


Source: Survey result (2015)

Source: From Bank and MDA composite data above.

The regression results on the composite pool data are as below.

Table 5. Summary Output

\begin{tabular}{|c|c|c|c|c|}
\hline \multicolumn{2}{|c|}{ Regression Statistics } & & & \\
\hline Multiple R & 0.994732 & & & \\
\hline R Square & 0.989491 & & & \\
\hline Adjusted R Square & -3.03153 & & & \\
\hline Standard Error & 0.874524 & & & \\
\hline Observations & 4 & & & \\
\hline \multicolumn{5}{|l|}{ ANOVA } \\
\hline & df & SS & MS & $\mathrm{F}$ \\
\hline Regression & 6 & 72.01239 & 12.0020648 & 31.38646 \\
\hline Residual & 1 & 0.764793 & 0.764792567 & \\
\hline \multirow[t]{2}{*}{ Total } & 7 & 72.77718 & & \\
\hline & Coefficients & Standard Error & t Stat & P-value \\
\hline IARS & 0.445947 & 6.118438 & 0.072885755 & 0.953681 \\
\hline CG & 0.176844 & 4.673247 & 0.037841683 & 0.975921 \\
\hline IC & 0.421334 & 5.401074 & 0.078009298 & 0.950438 \\
\hline AI & 0 & 0 & 65535 & \\
\hline $\mathrm{AE}$ & 0 & 0 & 65535 & \\
\hline WB & 0 & 0 & 65535 & \\
\hline
\end{tabular}

The above revealed that the model explains $99 \%$ of the variation in the response variable (FFFR) except for AI, AE and WB that have no linear relationship with it namely; AI, AE and WB. The F statistic of 31.38 at critical value of .011 (FDIST(31.386,4-3,3)) (Microsoft excel 2011) reveals that the equation has a good fit and that relationship amongst the constructs is significant and did not occur per chance. Therefore the null hypothesis is rejected and the alternative that there is significant relationship amongst the following variables; CS, CG and IC and Fraud Free Financial Report is accepted.

In addition the above regression results reveal the grand norm (country level) on application of the model on both the Bank (private sector) and MDA (public sector). The results also revealed that there is no linear relationship amongst AI, $\mathrm{AE}, \mathrm{WB}$ and FFFR but there is a linear relation amongst CS, CG, IC and FFFR. Therefore, the relevant coefficients in the result for our purpose are:

\begin{tabular}{ll}
\hline CS & 0.445947 \\
\hline CG & 0.176844 \\
IC & 0.421334
\end{tabular}

This result also reveals that $44 \%$ of $\mathrm{CS}, 17 \%$ of $\mathrm{CG}$ and $42 \%$ of IC predicts the response variable FFFR. Therefore, the grand norm in Nigeria is that to obtain FFFR emphasis was on CS, IC and CG in this order and, AI, WB and AE received little or no attention.

Specific application of the model on MDA (public sector) also revealed as follows:

Table 6. Composite Mda Data

\begin{tabular}{lrlrlrrr}
\hline & \multicolumn{1}{l}{ IARS } & CG & \multicolumn{1}{l}{ IC } & AI & \multicolumn{1}{l}{ AE } & WB & FFFR \\
\hline FFFR & 4.083515 & 3.783588 & 3.94335512 & 3.840959 & 3.82716 & 3.6492 & 5 \\
AAP & 4.239651 & 3.856209 & 3.976034858 & 3.860566 & 3.912854 & 3.7669 & 3.94 \\
DIS & 4.04793 & 3.775599 & 3.94335512 & 3.821351 & 3.856209 & 3.634 & 3.85 \\
VAL & 3.962963 & 3.718954 & 3.910675381 & 3.840959 & 3.712418 & 3.5468 & 3.78 \\
\hline
\end{tabular}


Table 7. Regression Results Summary Output

\begin{tabular}{lllll}
\hline \multicolumn{2}{l}{ Regression Statistics } & & & \\
\hline Multiple R & 0.992905 & & & \\
R Square & 0.985861 & & & \\
Adjusted R Square & -3.04242 & & & \\
Standard Error & 0.991915 & & & \\
Observations & 4 & & MS & F \\
ANOVA & & & 11.43376595 & 23.24185 \\
& df & SS & 0.983894567 & \\
Regression & 6 & 68.6026 & & \\
Residual & 1 & 0.983895 & t Stat & P-value \\
Total & 7 & 69.58649 & 0.025265879 & 0.983919 \\
& Coefficients & Standard Error & & \\
CS & 0.270435 & 10.70356 & 65535 & \\
CG & 0 & 0 & 65535 & \\
IC & 0 & 0 & 0.063255423 & \\
AI & 0.444118 & 7.021024 & \\
AE & 0.347729 & 13.79357 & 0.025209495 & 0.983955 \\
WB & 0 & 0 & 65535 & \\
\hline
\end{tabular}

Source: Microsoft excel (2010) toolpak

The above represent specific application of the model on the MDA (public sector) respondents. The results revealed that there is no linear relationship amongst CG, IC, WB and FFFR. Therefore, the relevant coefficients for fraud risk identification in the sector are:

\begin{tabular}{cr}
\hline CS & 0.27 \\
\hline AI & 0.44
\end{tabular}

$\mathrm{AE} \quad 0.34$

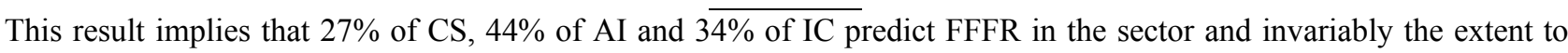
which we can rely on any of the three constructs to produce FFFR in the sector. Therefore, in this sector to obtain FFFR emphasis was on AI, AE and CS in this order and CG, IC and WB received little or no attention.

By this result investigation on MDA in Nigeria should concentrate on the identified core risk areas i.e. the extent of deviation of the above results from the grand norms (country level) which in the above case are CG, IC and the relative poor rating of CS (.27 as against .45 see Table 5.5 below). More importantly, in the public sector emphasis on implementation of Accounting standards is weak hence its rating is poorer than the grand norm rating. See the results below.

Table 8. Comparing Grand Norm and Public Sector

\begin{tabular}{lllr}
\hline & $\begin{array}{l}\text { Grand } \\
\text { Norm }\end{array}$ & & $\begin{array}{r}\text { Public } \\
\text { Sector }\end{array}$ \\
\hline CS & 0.445947 & CS & 0.27 \\
CG & 0.176844 & AI & 0.44 \\
IC & 0.421334 & AE & 0.34 \\
\hline
\end{tabular}

Source: Derived by the Researcher from the figures above

The results therefore are red flags indicating fraud prone areas in the sector.

\subsection{Test on Hypothesis Two}

The second research question is on whether courses in Nigerian Professional Accounting Institutes' syllabi are relevant in ensuring that Accountants have correct skill to detect and/or prevent fraud.

Outcomes of the test on the survey we conducted are as below.

$\mathrm{H}_{0}$ : Near absence of forensic accounting courses in the training programme of practicing accountants is not responsible for inability of auditors to detect WCC in Nigerian public sector. 
Table 9. Statistical Computations for Test on Hypothesis Two

\begin{tabular}{|c|c|c|c|c|c|c|c|c|}
\hline & & $\mathrm{x}$ & $\mathrm{f}$ & $f x$ & $\mathrm{X}-\mathrm{X}$ & $(X-x) 2$ & $f(X-x) 2$ & \\
\hline SA & & 5 & 12 & 60 & 2.784797 & 7.755092 & 93.0611 & \\
\hline A & & 4 & 120 & 480 & 1.784797 & 3.185499 & 382.2599 & \\
\hline $\mathrm{N}$ & & 3 & 207 & 621 & 0.784797 & 0.615906 & 127.4925 & \\
\hline D & & 2 & 313 & 626 & -0.2152 & 0.046313 & 14.49582 & \\
\hline SD & & 1 & 282 & 282 & -1.2152 & 1.476719 & 416.4349 & \\
\hline \multirow[t]{7}{*}{$\sum$} & & 15 & 934 & 2069 & 3.923983 & 13.07953 & 1033.744 & \\
\hline & Mean & & $\sum \mathrm{fx} /$ & & & & & 2.215203 \\
\hline & $\partial$ & & $\sqrt{(}(\mathrm{c}$ & & & & & 1.052042 \\
\hline & $\mathrm{Se}$ & & $\alpha /(\sqrt{2})$ & & & & & 0.034424 \\
\hline & $v$ & & $x+-$ & & first & & & 2.282674 \\
\hline & & & & & secound & & & 2.147733 \\
\hline & caculated Z & & $(\mathrm{x}-\mathrm{v})$ & first & & & & $\begin{array}{l}-1.94767 \\
1.956395\end{array}$ \\
\hline
\end{tabular}

Source: Result of the Feld work by the researcher (2015)

Decision: accept null hypothesis since calculated Z (-1.94767 is greater than critical Z (-1.96)

and calculated Z (1.956395) is less than critical Z (1.96)

Associated P-value:

Two tailed test: Using Standard Normal Distribution table

$$
\begin{gathered}
\mathrm{P}(\mathrm{z}<-1.94767)=.0262 \\
\mathrm{P}(\mathrm{z}>1.956395)=.025 \\
\mathrm{P} \text {-value }=.0262+.0256 \\
=0.0518
\end{gathered}
$$

Since P-value is greater than the significant level $(0.05)$ we accept the null hypothesis.

We therefore accepted the null hypothesis that near absence of forensic accounting courses in the training programme of practicing accountants is not responsible for inability of auditors to detect fraud in Nigerian public sector.

\section{Discussion of Findings}

The study established that there is a significant relationship amongst the following variables; CS, CG and IC in determining Fraud Free Financial Report. That in Nigeria to obtain FFFR emphasis was on CS, IC and CG in this order and, AI, WB and AE received little or no attention. Application of the model in the study at firm or subsector level reveals fraud prone areas in the subsector/firm thereby becomes a barometer (investigation tool) that flags off fraud risk. The results therefore revealed that reliance on accounting standards to combat fraud should not be total because other variables such as IC and CG are significant in determining FFFR. Thus affirming our earlier deduction from literature that accounting standards are tools for combating $25 \%$ of the eight elements in fraud management cycle and $75 \%$ are within the purview of Forensic accounting.

Note that the models ascertained the perception of the professionals in the area under examination at a point in time (cross sectional analysis). That is to say the ratings in this study may change with passage of time. Overall the model revealed that it is only WB that suffered neglect in both country level and specific level implying that Nigeria is not giving attention to whistle blowing as a panacea to Fraud.

Although professionals targeted in the study asserted that near absence of forensic accounting courses in the training programme of practicing accountants in Nigeria is not responsible for inability of auditors to detect WCC in Nigerian public sector, there is an urgent need for the two bodies regulating accounting practice in Nigeria to respond to global environmental changes by adjusting their respective curriculum. Modern sophistication which is gradually catching up with the country especially rapid growth in information technology and increases in cybercrimes indicates that there is need for curricula adjustments by the professional bodies in order to enable their members meet the challenges of modern time. Both bodies for now do not provide courses such as criminology and criminal psychology to qualify their members to practice accountancy in Nigeria. However in recent time ICAN appears to be making up for this lapse by creating faculty of forensic accounting which again is not mandatory to their members. Note that forensic accounting incorporates criminology and criminal psychology; it is our view therefore that such courses and indeed courses in forensic accounting should be mandatory in the training programme for all their members. It follows then and in consonant with Brett (2006) findings that the standards and legislation no matter how well intended cannot be effective unless they are properly incorporated into the education curriculum of accounting professionals. 


\section{Conclusions}

This study revealed that there is a significant relationship amongst the following variables; CS, CG and IC in determining Fraud Free Financial Report. That in Nigeria to obtain FFFR emphasis was on CS, IC and CG in this order and, AI, WB and AE received little or no attention. The study also revealed that from extant literature Accounting Standards (IARS inclusive) are tools for combating $25 \%$ of the eight elements in fraud management cycle while $75 \%$ of them are within the purview of Forensic accounting. Hence it is our view that forensic accounting courses should be incorporated into the curriculum of professional accounting bodies in order to equip their members with sufficient skills that would enable them effectively perform the duties expected from public accountants

\section{Recommendations}

i. Forensic accounting courses should be incorporated into the final level professional examination of the two accounting bodies regulating accountancy practice in Nigeria.

The following areas should receive attention. Quantitative Techniques: Data analyses software such as E-view, SAS, SPSS, Minitab, Microsoft Toolpak. Interrogation tools for computers (CAAT and CAATT) (eg Dedicated AATTs Analyzer, Audit command Language (ACL), ESKORT computer audit (SESAM), Interactive Data Extraction and Analysis (IDEA), TOP CAATS and Enterprise Resource Planning Solutions - ERP (SAP, ORACLE .....). Notable courses in Forensic Accounting (eg Legal methodology, Criminal litigation:, Stages of investigation, criminal procedures, rules, pre-trial hearing, Law of evidence, Initial hearing to completion of trial - rules and principles, the burden of proof, rules governing advocacy and trials, Electronic crime - using computer to combat such crimes, litigation support, Expert witness, Fraud examination courses).

ii. Confidentiality and protection of whistle blowers should be enshrined in Nigerian laws especially those that created the regulatory agencies such as Security and Exchange Commission, Corporate Affairs Commission, Central Bank of Nigeria etc. In other words the public should also be given opportunities to cry out whenever they observe infractions on Accounting Standards and similar issues.

\section{Acknowledgements}

I wish to express my gratitude to Professor B. C. Osisioma and Professor Emma I. Okoye whose intellectual inputs greatly assisted me during the study. I also acknowledge the critique of this study by Dr. Nzewi and Dr. Ebuh Godday who diligently assisted in shaping the study. My gratitude also goes to every person who assisted me in carrying out this study especially the banks and government institutions that provided the primary and secoundary data for the study. I am grateful to Mr Nenyiaba Kaly my able research assistant for his Data collection efforts and proof reading skills. He proof read the manuscript. God bless you all.

\section{References}

Adeyemi, S. B. (2005). The Impact of Accounting Standard on Financial Reporting, Unpublished Ph. D. Thesis, Department of Accounting, University of Lagos.

Ayittey, B. N. G. (2006). Nigeria's Struggle with Corruption, A testimony before the Committee on International Relation's Subcommittee on Africa, Global Human Rights and International Operations House Committee on Africa, U.S. House of Representatives, Washington, D.C, Thursday, May 18.

Brett, A. (2006). Crazy, maybe, but listen to this crook, Boston Herald October 6th.

Courtis, J. K. (1992). The reliability of perception-based annual report disclosure studies, Accounting and Business Research, 23(89), 31-43.

Ezejelue, A. C., Ogwo, O. E., \& Nkamnebe, A. D. (2008). Basic principles in managing research projects, Afritowers limited. ISBN 978-35517-7-9.

Firer, C., \& Meth, G. (1986). Investor information requirements and disclosure in annual Reports. The Investment Analysts Journal, 27(1), 11-17.

FITC (2013). Fraud Detection and Investigation CBN experience-workshop for bankers by Financial Institution Training Centre.

Iyoha, F. O. (2011). State Agencies, Industry Regulations and The Quality of Accounting Practice in Nigeria, AnUnpublished Ph. D thesis submitted to The School of Post graduate Studies, Covenant University, Ota, Ogun.

Izedonmi, F. O. (2001). An Evaluation of The level of Banks' Compliance with Accounting Standard, Issued by Nigeria Accounting Standard Board, The Nigerian Bankers, 24 (4), 12-15.

Oghuma, R., \& Iyoha, F. (2005). Compliance with Accounting Standards by Quoted Insurance Companies in Nigeria: 
An Empirical Investigation. Nigerian Journal of Education Research, 7(2), 18-27.

Osisioma, B. C. (2012). Combating Fraud and White Collar Crimes: Lessons from Nigeria. A paper presented at 2nd Annual Fraud \& Corruption Africa Summit, Held at Zanzibar Beach Resort, Zanzibar Republic of Tanzania.

Wallace, R. S. O. (1988). Corporate Financial Reporting in Nigeria. Accounting and Business Research, 18(72), 352-362.

Wesley, K. W. (2004). The Fraud Management Lifecycle Theory: A Holistic Approach to Fraud Management. Journal of Economic Crime, 2(2). 


\section{Appendix}

\section{Research Questionnaire}

Department of Accountancy, Faculty of Management Science, Nnamdi Azikiwe University, Awka, Anambra State, Nigeria

Dear Respondent,

\section{Evaluation of Key Determinants of Fraud Free Financial Report}

The questions below are part of a research work which seeks to obtain information on the above subject. The resultant article will be submitted to the Department of Accountancy, Nnamdi Azikiwe University Awka. Any information given in this regard will be highly appreciated.

We shall treat all information disclosed to us in the strictest confidence. We strongly appeal for your kind support.

Researcher:

Nenyiaba Ile Charles.

\section{Section a}

Respondent Bio- data

Please circle the appropriate response

1.
a. Your Gender:
(a) Male
(b) Female

b. Your highest academic qualification:
(i) HND
(ii) B.Sc/BA
(iii) $\mathrm{MBA} / \mathrm{MSc} / \mathrm{MA}$ (iv)
$\mathrm{PhD}(\mathrm{v})$ Others (specify)

c. The professional body you belong to:

(i) Institute of Chartered Accountants of Nigeria (ICAN) (ii) Association of National Accountants of Nigeria (ANAN) (iii) ACCA (iv) CPA (v) Others (specify)

d. Your professional Status: (i) Fellow (ii) Associate (iii) Others (specify)

2. Which of the following group do you belong?

(i) Ministry, Department or Agency of government

(ii) Bankers 


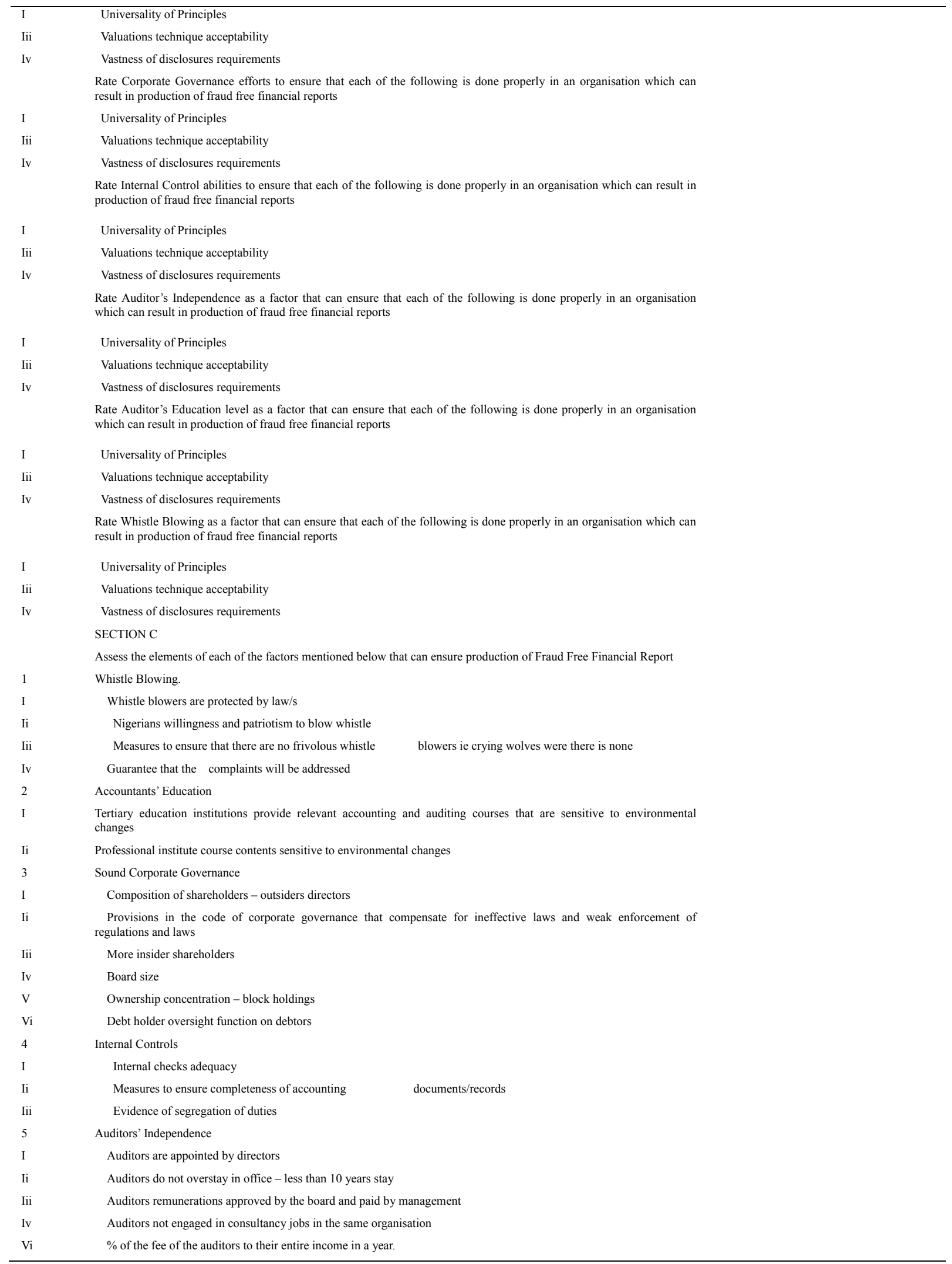




\section{Section D}

$\mathrm{SD}=$ Strongly Disagree $\mathrm{D}=$ Disagree $\quad \mathrm{N}=$ Neutral $\mathrm{A}=$ Agree $\mathrm{SA}=$ Strongly Agree

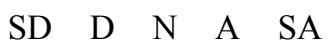

Absence of forensic accounting courses in the training programme of practicing accountants is not responsible for inability of auditors to detect White Collar Crimes in Nigerian public sector.

\section{$((c))$ EY}

This work is licensed under a Creative Commons Attribution 3.0 License. 